\title{
Narratives on the Rescue of the Infant Jesus in the Russian Folk "Bible" (Siberian Russian Texts)
}

\author{
V. S. Kuznetsova \\ Institute of Philology, Siberian Branch of the Russian Academy of \\ Sciences, Novosibirsk, Russia
}

Stories about the miraculous rescue of the infant Jesus are common among folk narratives related to events in the gospels. In the rescue stories, the Virgin Mary and her infant are pursued by hostile forces. The Virgin Mary then asks a woman to throw her own child into the stove, to take Christ into her arms and to pass him off as her own. The child in the stove remains miraculously unharmed. In other versions it is Jesus Christ himself who does the asking. Similar stories appear in nineteenth-century manuscripts as well. One example is the following from the Smolensk guberniia: [Dobrovol'skii 243-244]

[1] Гаспоть ат акаянных жидоў ускачіў у горницу, а там жэнщина кормить грудью дитёнка.

Гаспоть крикнул на жэнщину:

- Дитенка брось у печь, а мяне вазьми!

- Божжа мой, да іон згарить!

- Нябось! ничога нябудить твайму дитёнку, Толька тоя делай, што я скажу.

Баба бросила свайго дитёнку у печь, а Христа узяла к сабе на руки. //

Жиды тоя видють, щто баба укинула дитёнка у в агонь, а тога ня видють, што Христос на руках, а дитёнык тэй на тую пару-ўремичка бутца крикнуў у печи.

Забили жиды у ладони:

- Христа спалили, спалили, спалили!

Дитёнык пириставіўся весь у твитах и стал у святых, а Христос пашоў с двинацытью апосталами.

The Lord ran from the cursed Jews into a hut, and a woman is breastfeeding her child in there.

The Lord yelled at the woman:

-Throw the child into the stove and take me!

-My God, but he will burn up!

-Do not fear! Nothing will happen to your child. Only do what I say.

The woman threw her own child into the stove and took Christ into her arms.

The Jews saw that the woman had thrown the child into the fire, but did not see that

Christ is in her arms, but the other child at that moment was crying in the stove.

The Jews began to clap their hands:

- Christ has been burned up, burned up, burned up!

FOLKLORICA 2007, Vol. XII 
The child turned out to be covered in flowers and became a saint, and Christ went with his twelve apostles.

We find the same plot in a story recorded a hundred years later in the Gomel' oblast'. There the motif of the miraculous rescue from the stove is conflated here with the motif of the miraculous growth of vegetation: [Belova 2004: 316-317]

[2] По ўсим сельсоветам приказали хлопчикам отсекать головы. А Матерь Божья с Иисусом узнала и убежала от властей. [Одна женщина приютила еe, спрятала Иисуса в печку и закрыла заслонку. Преследователи его не нашли. Пошла Матерь Божия с Иисусом дальше. Видит - сеет мужик пшеницу.]

- Сеете пшеницу?

- Сею.

- Заўтра жать будете. //

Што это там за ўопросы, заўтра жать? [Удивился, пошел домой. А назавтра выходит - пшеница поспела. Едут стражники, спрашивают, не видал ли тут проходящую женщину с ребенком маленьким? Отвечает видал.]

- А колИ она шла?

- Да кады пшаницу сеял.

[Стражники думают: э, как давно! - и повернули обратно.] Етым сло́вам йих атверну́ла.

Приходит яна́ к речке 3 хлопчиком з е́тым. [А на берегу играют дети у лодки. Она просит их перевезти на тот берег, а они отвечают: «У нас лодка поломана». - «Ничео, все будет хорошо». И верно, лодка оказалась в порядке, и хлопчики благополучно перевезли Богоматерь с младенцем.]

In every village they ordered that every boy should be beheaded. And the Mother of God discovered this and ran away from the authorities with her son. [One woman sheltered her, and hid Christ in the stove and closed the stove-door. The pursuers did not find him. The Mother of God and Jesus went on farther. She sees that a peasant is sowing wheat.]

-Are you sowing wheat?

-I am.

- Tomorrow you will harvest it. //

What kind of questions are these, harvest tomorrow?

[He was amazed and went home. But in the morning he comes out and the wheat had matured. Some constables are riding by and they ask, have you seen a woman going by with a boy child? He answers, I have.]

-And how long ago did she pass by?

-When I was sowing wheat.

[The police think, "oh, that was so long ago!" and they turned back.] With these words she turned them back.

She comes to a little river with the boy. [And on the shore children are playing in a boat. She asks them to take them to the other shore, but they 
answer: "Our boat is broken." -"Don't worry, everything will be fine." And truly, the boat turned out to be fine, and the boys successfully took the Virgin Mary and her child across.](1)

Similar stories are also common in Siberian Russian manuscripts. We will examine two instances of this plot in publications dated to the second half of the nineteenth century. One of them was collected on the territory of western Siberia in Tomsk guberniia and the other in eastern Siberia in Irkutsk guberniia, Tukin Valley: [Potanin 121]

[3] Маленький Христос, преследуемый, просил Улиту спрятать его. Улита своего собственного сына бросила в топившуюся печь и Христа положила в зыбку: преследователи не нашли Христа и только вышли вон, мать подошла к печке, а там Кирик стоит “иставленный” (целый).

The Christ-child, who was being followed, asked Ulita to hide him. Ulita threw her own son into the lit stove and put Christ into the cradle: the pursuers did not find Christ and as soon as they had left, the mother went to the stove, and there Kirik was standing "in one piece" (whole).(2)

[4] ... как только жиды узнали о рождении Христа, то бросились его искать, чтобы убить, но никак не могли найти. Тогда стали жечь всех ребят; одного парнишку бросили в печь, когда матери его не было дома: мать вернулась, посмотрела в печь, а там в огне сидит парнишка и играет угольками!

... as soon as the Jews found out about the birth of Christ, they set about searching for him to kill him, but they couldn't find him. Then they began to burn all the children; they threw one little boy into the stove, when his mother was not home; his mother returned, looked into the stove, and there in the fire the little boy was sitting playing with the coals! [Astyrev 39]

Later manuscripts of such stories from the 1950s and 1970s also exist, as in this text from the Tomsk oblast':

[5] ... и, значит, напали на ево [Христа] жиды и хотели ево сжечь в огне. Он от их убежал, вбежал в избушечку, а там сидит женщина и кормит младенчика. Старичок он был и говорит: «Женщина, бросьте сваво младенца в печь, пускай он сгорит». Она сначала не хотела, а он сказал, что ему смерть. Женщина бросила младенца в печь. Младенец перевертываца и начал там играть свиточками. Он говорит: «Возьмите меня на руки и прижмите меня к своей груди». Она взяла старика на руки и прижала его к своей груди. А он и сделался маленьким мальчиком в пеленочках. Жиды забежали, его не нашли.

... and, that means, the Jews attacked him and wanted to burn him in the fire. He ran away from them, ran into a little hut, and there a woman is sitting 
feeding her little child. He was in the form of a little old man and says: "Woman, throw your child into the stove, let him burn." At first she didn't want to, but he said that he would die otherwise. The woman threw the child into the stove. The child turned around and began playing with the coals. $\mathrm{He}$ says: "Take me into your arms and hold me to your breast." She took the old man into her arms and held him to her breast. And he turned himself into a small boy in swaddling clothes. The Jews ran in, but didn't find him. [FA OmGPU 1951, No. 60] (3)

[6] Искали Иисуса Христа. Спрятала его цыганка у себя в печке. Когда пришли в дом, она стала подкладывать мелкие щепочки в печку, делая вид, что зажигает, а сама отодвигала их дальше. Так и не нашли Иисуса. Поэтому нельзя винить цыганку, что она крестится: она Иисуса спасла,

They were searching for Jesus Christ. A gypsy woman hid him in her stove. When they came into the home, she began to throw small threads into the stove, giving the impression that she was burning them up, but actually she was moving them farther away. So they didn't find Jesus. Therefore, you cannot blame the gypsy woman for taking the Lord's name in vain; she saved Jesus. [FA OmGPU 1973, No. 31] (4)

A similar narrative about the rescue of the infant Jesus also exists in verse. The religious song about the almswife, Miloserdnaia (lit. Merciful) was, according to G.P. Fedotov, widespread and known "under the title of Allilueva's wife." [Fedotov 39]

We will examine a variant of this religious verse from the $\mathrm{P}$. Bessonov collection, No. 321, Vallaiskii uezd, village of Bor...recorded from the blind peasant Larion: [Bezsonov 118-121]

\author{
Милостивая жена Милосердная \\ Топила во граде свою келью, \\ Держала своего чада на ручах. \\ К Милостивой к Жены Милосердныя \\ Иде сама Дева Пресвятая, \\ Несе самого Христа Бога на руцах: \\ «Милостива жена Милосердная! \\ Бросай ты свое чадо в огонь и пламя, \\ ты бери самого Христа Бога на руци: \\ Бегут жиды-супостаты \\ с оружьям и с вострыим копіям, \\ хотят Христа Бога убити». \\ Милостива Жена Милосердная \\ Бросила свое чадо в огонь и пламя, \\ Брала самого Христа Бога на руци. \\ Жиды-супостаты набежали \\ С оружьями, с вострыими копіям, \\ Жену Милосердную Жиды да спрошали: \\ «Милостива Жена Милосердная!
}


Давно ль ты Христа Бога видала?»

Милостива Жена им отвечала:

- Ой же, Жиды-супостаты!

Я теперь Христа Бога поймала, Я в огонь во пламень его вогнала.

Жиды к огненной печи приходили:

Во печи младенец стрепехнулся, Показал жидам он руци и ноги.

Жиды-супостаты срадовались: «Мы теперь Христа поймали, Мы в огонь во пламя его загнали, Медным заслоням заслоняли, Зелезныим подпорам подпирали!» Жиды прочь от печи отходили. Милостивая Жена Милосердняя Не могла Христа Бога соде́ржать, На его на светлость наглядеться: Не стало Христа у ей на ручах. Милостива жена Милосерная К огненной ко печи приходила: - Ужо ль там сгорело мое чадо? Зелезныи подпоры отпирала, Медныи заслони отслоняла:

Во печи трава выростала, На травы цветы разцветали, Во цветах младенец играет, На нем риза солнцем возсіяет, Евангельскую книгу сам читает, Небесную силу прославляет, И со ангелами, с херувимы И со всею с небесною силой. Милостива Жена Милосердная Она первая в раю пребывает. Аллилуя, аллилуя, аллилуя, Мы славим Тебе, Христа и Бога!

The almswife Miloserdnaia Was heating her cell in the city, While holding her child in her arms. To the Almswife Miloserdnaia Came the Holy Virgin herself, Carrying the God Christ himself in her arms:

"Almswife Miloserdnaia!

Throw your child into the fire and flame,

Take the God Christ himself into your arms:

The Jews, the foes are coming with weapons and with sharp spears, they want to kill the God Christ."

Miloserdnaia the Almswife Threw her child into the fire and flame, 
She took the God Christ into her arms.

The Jews, the foes came running in

With weapons, with sharp spears,

And the Jews asked Miloserdnaia the Almswife:

"Almswife Miloserdnaia!

Have you seen the God Christ recently?"

The Almswife answered them:

-Oh, the Jews, the foes!

have just caught the God Christ,

I drove him into the fire, into the flame.

The Jews came to the fiery stove:

The child was whimpering in the stove,

He showed the Jews his arms and legs.

The Jews, the foes were overjoyed:

"Now we have caught Christ,

We drove him into the fire, into the flame,

We have closed him in behind the bronze stove-door,

We have locked him in with iron bars!"

The Jews went away from the stove.

Miloserdnaia the Almswife

Could not hold the God Christ,

Could not bear to look upon his brightness;

Christ did not remain in her arms.

Miloserdnaia the Almswife

Went to the fiery stove;

-Has my child really been burned?

She slid back the iron bars,

She opened the bronze stove-door;

Grass was growing in the stove,

On the grass flowers had bloomed,

In the flowers the little child is playing,

Upon him a ray of sun is shining,

He is reading the Gospels by himself,

$\mathrm{He}$ is praising heaven's power,

And with the angels, and the cherubim,

And with all of heaven's forces.

Miloserdnaia the Almswife

She will be first in heaven.

Alleluia, alleluia, alleluia,

We give praise to you, Christ and God!

There are two versions of this religious song. In the first, the Virgin Mary turns to the almswife with her request. This version is represented in the variant translated above. We also find it in one of two variants of the religious song about the Almswife Miloserdnaia found in the Varentsov collection (Nos. 55-56, obtained "from the Sreznevskii acathistus"). [Varentsov 177-178] 
According to the other version of this religious song, it is not the Mother of God that makes a request of the wife, but the Savior himself: [Bezsonov No. 323, p. 124]

Из граду молоденец утекает, На путь на дорогу нападает.

На пути ли на дороге

Жила Же́на Милосе́рдная:

Перед нею горит огонь-пламень,

На ру́цах держала младенца;

Истинный Бог возвещает:

Же́на Милостивая Милосе́рдная!

Брось ты свою чаду в огонь-пламень,

Прими ты Христа Бога на руцы

The boy escapes from the city,

He is attacked on the path, on the road.

On the path, on the road

Lived Miloserdnaia the Almswife:

Before her a fire, a flame is burning,

She was holding a child in her arms;

The True God proclaims:

Miloserdnaia the Almswife!

Throw your child into the fire, into the flame,

Take Christ the God into your arms. (5)

Christ himself reassures the almswife and prompts her to open the stove to find her own son unharmed: [Bezsonov No. 325, pp. 129-130]

Истинный Христос, сын Божий,

Невведим проре́чил:

«Милостива Жена Милосердна!

Твоё чадо не согрело,

Твоё милое ни в чем невредимо:

Твоё чадо по печи гуляет,

Святое Евангелье читает,

Ангелы младенца утешают».

Милостива жена не поверила,

Во огненну печь заглянула:

По Божьему суду-изволенью,

Во пламе трава выростала,

Лазоревы цветы расцветали.

Милостива Жена перекрестилась:

- Премудр Господь, Сыне Божий,

Премудра твоя небесная сила!

The True Christ, God's son,

Unharmed said:

FOLKLORICA 2007, Vol. XII 
"Miloserdnaia the Almswife!

Your child did not burn,

Your dear one has not been harmed:

Your child is walking around in the stove,

He is reading the Holy Gospels,

The angels are comforting the child."

The almswife did not believe him,

She glanced into the fiery stove;

In accord with God's will and judgement,

Grass had grown up in the flame,

Azure flowers had bloomed,

The almswife crossed herself;

Oh, most wise Lord, Son of God,

Your heavenly forces are the most wise!

We also find this version in a Siberian Russian text recorded by P A. Gordnov on the 15th of June 1907 in the Tobol guberniia from the peasant Dmitrii Nikiforovich Plekhanov: [RGALI, file 1366, list 1, unified collection 177 , sheets 5-6, no. 3]

Еще Жúды Христа потеряли,

И Христос Бог из града убегает,

Он на путь на дорожку поступает

И до села до деревни добегает.

И приходит Христос Бог во селенье

К Жене Милостивой Милосердной.

Жена Милостивая Милосердная,

Она держит младенца на руцах

Ей Христос Бог возрещает:

- Жена Милостивая Милосердная.

Брось ты свое милое чадо в огонь-пламень,

Возьми ты Христа Бога на руци!

Жена Милостивая Милосердная

Бросила милое чадо в огонь-пламя

И взяла Христа Бога на руци.

Набежали Жиды Жидовины

К Жене Милостивой Милосердной:

- Жена Милостивая Милосердная,

Ты куда Христа Бога сподевала?

- Я бросила Христа Бога в огонь-пламя.

И в огне-пламе младенец стрепескался.

И оказал Жидовинам руци-нозии.

Ишшо в то́поры жиды зрадовалися,

Заскакали Жиды, заплясали,

В щелчки Жидовоё защелкали.//

Жена Милостивая Милосердная.

Она плачет об чаде милом.

Ей Христос Бог возрещает: 
- Жена Милостивая Милосердная!

Ты не плачь, не тужи об чаде об милом

Твое милое чадо не сгорело.

Не сгорело чадо милое, не изотлело.

Он во церкви по печке [?] гуляет

И евангельскую книгу читает,

Он сам себе имя нарекает.

Он нарекает себе имя: Аллилуйа,

Аллилуйа, слава Боже, Аллилуйа.

The Jews had lost Christ,

And the God Christ is running from the city,

And sets out on the way, on the road

And he runs to a town, to a village,

And the God Christ comes into the village

To the Miloserdnaia the Almswife.

Miloserdnaia the Almswife,

She is holding a child in her arms

The God Christ exclaims to her:

- Miloserdnaia the Almswife,

Throw your dear child into the fire, into the flame,

Take the God Christ into your arms!

Miloserdnaia the Almswife

Threw her dear child into the fire, into the flames,

And took the God Christ into her arms.

The Jewish Jews came running

To Miloserdnaia the Almswife:

- $\quad$ Miloserdnaia the Almswife,

What have you done with the God Christ?

- I threw the God Christ into the fire, into the flames.

And in the fire, in the flames a boy was whimpering

And he showed the Jews his hands and legs.

The Jews already at that time began to rejoice,

The Jews began to jump, to dance,

The Jews began to snap their fingers.//

Miloserdnaia the Almswife,

She is crying about her dear child.

The God Christ exclaims to her:

- Miloserdnaia the Almswife!

Do not cry, do not grieve for your dear child

Your dear child has not been burned.

The dear child has not been burned, has not been turned to ash.

$\mathrm{He}$ is walked around the stove in the church

And reading the Gospels,

He himself is speaking a word to himself.

$\mathrm{He}$ is saying to himself the word: Alleluia,

Alleluia, Glory to God, Alleluia. 
The content of the Verse about Miloserdnaia the Almswife indicates that folkloric legends about the rescue of the child in the stove represent essentially a prose retelling of the plot of this religious song. It appears that a religious song was the direct source for the folk legends examined here. Furthermore, the distinction between the two versions of the legends corresponds directly to the two versions of this verse that we have cited. Thus we find the first version, in which the Virgin Mary asks for help, is the antecedent of one of the legends (see 2 above); while the others are associated with the second version, in which Christ himself asks for help. It is noteworthy that the variants of the second version of the song are also more numerous.

It should be noted that another motif, namely the miraculous growth of vegetation, also exists in one variant (see 2 above) of the legend and may also be inspired by a religious song, specifically a song about the flight to Egypt: [Bezsonov No. 319, pp. 116-117]

\footnotetext{
Шла Божія Матерь полем и встретила селянина, -

сеет пшеницу; сказала ему Пречистая:

Помогай Биг, убогій седлячку!

Будуть ту ити Жиды й Жидивки,

Жиды й Жидивки й Жидивськи дивки, -

Поведай же ты, же я тады йшла,

Коли ты ту орав, пшеничейку сеяв».
}

Только что ушла Святая Дева за гору, набежали Жиды, и Жидовки, и Жидовски девки, и видят - селянин жнет пшеницу. Спрашивают они о той (белоголовой ) женщине, не шла ли мимо его?

Шла, - говорит селянин, - тогда шла,

Коли я ту орав, пшеничейку сеяв:

А теперь уже пшеничейку зажав.

Говорят Жиды:

- Коли ж то було, коли вин ту орав,

А теперь вин пшеничейку зажав!

The Mother of God was going along the fields and she met a peasant,-

He is sowing wheat; And the Most Pure said to him:

God help you, poor peasant!

Jews and Jewesses will come to you,

Jews and Jewesses and Jewish girls,-

You tell them that I have gone that way,

When you had ploughed and were sowing the wheat.

As soon as the Holy Virgin had disappeared behind the mountain, the Jews and Jewesses and Jewish girls ran up and they see that the farmer is harvesting wheat. They ask him about this (blonde) woman, Has she come by, by any chance?

She came by, -the peasant says, and then went,

When I had ploughed and was sowing the wheat: 
And now I have already harvested the wheat.

The Jews say:

-It was then when he had ploughed,

And now he has harvested the wheat!

It is significant that the text cited here has a note: "In Christmas songs of the Carpathian mountain dwellers; compare Kostomarov "On the historical meaning of Russian folk poetry," pp. 18-19". This would indicate that the motif of the miraculous growth of vegetation presented in the song and in the legend ( 2 above) stems from a single locale. [cited in Bezsonov 117]

In prose folk narratives the so-called merciful woman (see 1, 2, 5 above) is not the Christ child's only savior. In some texts of this song we also find a gypsy woman (see 6 above) or Saint Ulita and her child Kirik.

The motif associated with the gypsy who, as a reward for her actions, can deceive people and take God's name in vain is well attested in folklore. See, for example, SUS 790*-AA *847-K 790 (The Golden Stirrup). Here Saint George teaches a poor man (Nesterka, Savvochka, a Gypsy), how to live if he wants to get rich, to steal and lie. The poor man steals a golden stirrup (a golden saddle, a golden goblet) from the saint and denies it. There is another explanation for the fact that the Gypsy (man or woman) can deceive others and take the Lord's name in vain without punishment. This is found in folk narratives associated with events in the Gospels, such as the crucifixion of Christ. Here a Gypsy man (or woman) was not afraid to lie to save Christ. When his torturers wanted to kill the Savior with a nail to his forehead or his heart, the Gypsy passes off a fly (or a bee) as a nail and saves Christ. (7)

How then did the plot about the rescue in the stove come to be associated with the names of Kirik and Ulita? In the canonical version, the life and martyrdom of these saints has never been associated with the stove or fire. In the version of the life of these saints presented in religious song, however, we do find such a motif. (8) It is associated with that episode when the pagan emperor Maximilian orders that his wife Ulita and the child Kirik be thrown into a cauldron burning with fire and flame because they 'believed in the faith of the Lord' and refused to pray to false idols. (9) In the intital portion of the song we also find the motif of the flight of the Chrisitan Ulita from the city, where the pagan emperor rules: [Varentsov 77-86]

Во славном было в городе в Домостеев,

Жил-был неверный царь Максимиан;

У него была честная жена Улита; 
Она веру веровала ко Господу;

Избежала из-под городу из Домостеева

Во тот во Евсеев город.

Неверный царь Максимиан

Он посланников за нею посЫлывает,

За честною женою Улитою,

В тот во Евссев город.

Еще взяли - возвратили в Домосеев город //

Ко неверному царю Максимиану.

Неверный царь Максимиан

Он честной жене обрадовался; <...>

- «Честная жена Улита,

Будешь ли ты мою веру веровать?

Будешь ли моим идолам молитися?»

[Улита и сын ее - младенец Кирик - отвечают отказом, тогда]

Неверный царь Максимиан

На святого младенца на Кирика

Он пуще на него озлобился,

Приказал он его на мученье взять,

На мученье взять на великое. <..>

Приказал он наносить в котел

Свинцу, смолы и олова,

Разжигать жаром-огнем-пламенем.

Наносили в котел свинцу, смолы, олова,

Разжигали жаром-огнем-пламенем,

Заревел-закипел котел, ровно гром загремел,

Слышно было на тридцать верст.

Устрашилась его родимая мати,

Честная жена Улита:

Она злую думу задумала,

Отстает она от Спаса от Пречистаго,

От Матери Пресвятыя Богородицы.

Она хочет неверному царю Максимиану прилеститися;

Она хочет его веру веровать,

Она хочет его идолам молитися.

Святой младенец Кирик,

Трех лет без трех месяцев

Жалко вопиюще гласит

Ко Царю ко Небесному:

«Господи, Отец, Сын, Святой Дух!

Услышьте молитву святаго младенца Кирика, -

Не отдайте на великое мучение

Со родимою со матерью

Ко царю ко неверному,

Уймите мою родимую матерь!

Она злую думу задумала:

Отстает она от Спаса от Пречистаго,

От Матери Пресвятыя Богородицы».

Услышал Господи мотиву святаго младенца Кирика. < ..> 
Оградил Господи котел животворящим крестом,

Выросла в котле трава-мурава,

Розцвели цветы лазоревые,

Святой младенец Кирик

Жалко вопиюще глаголет

Ко царю ко неверному:

«Неверный царь Максимиан!

Погляди-ко у нас в котле трава-мурава,

И розцвели цветы лазоревые.

Велика наша вера крещеная,//

Велик наш христианский Бог!»

Еще славен Бог прославися,

Прославился святой младенец Кирик,

Трех лет без трех месяцев,

Со родимою со матерью,

С честной женой со Улитою,

Пошла эта слава по всей земле,

По всей земле, по святой Русе.

От нынешняго житья-бытья и до́ веку. Аминь.

It was in the glorious, in the city in Domosteev,

There lived, there was a pagan emperor Maximilian;

He had an honorable wife Ulita;

She believed in the faith of the Lord;

She ran way from the city, from Domosteev

Into that, into Evseev city.

The pagan emperor Maximilian

He sends pursuers after her,

After his honorable wife Ulita,

Into that, into Evseev city.

They have caught her and returned to Domosteev city//

To the pagan emperor Maximilian.

The pagan emperor Maximilian

He rejoiced to his honorable wife; $<\ldots>$

- "Honorable wife Ulita,

Are you going to believe in my faith?

Are you going to pray to my idols?"

[Ulita and her son, the child Kirik, refuse, then]

The pagan emperor Maximilian

At the holy child, at Kirik

He got most angry at him,

He ordered him to undergo torture,

To undergo great torture. $<\ldots>$

He ordered that they carry in a cauldron

With lead, tar and tin,

Light it with heat, fire and flame.

They carried in a cauldron with lead, tar, tin,

And they lit it with heat, fire and flame,

The cauldron roared and boiled, just like thunder, 
You could hear it for thirty versts.

His dear mother was frightened,

The honorable wife Ulita;

She began to think evil thoughts,

Would she remain apart from the Most Holy Savior,

Apart from the Most Holy Mother, Mother of God.

She wants to submit to the pagan emperor Maximilian;

She wants to accept his faith,

She wants to pray to his idols.

The holy child Kirik,

Three years old less three months

Pitifully cries out

To the Heavenly Ruler:

"Lord, Father, Son, Holy Spirit!

Hear the prayer of the holy child Kirik, -

Do not allow him to be subject to great suffering

With his dear mother

To the pagan emperor,

Take my dear mother!

She has begun to think evil thoughts:

Would she remain apart from the Most Holy Savior, Apart from the Most Holy Mother, the Mother of God."

The Lord heard the prayer of the holy child Kirik. <...

The Lord protected the cauldron with a life-giving cross, Grass grew in the cauldron,

Azure flowers bloomed,

The holy child Kirik

Cries out piteously

To the pagan one, to the emperor:

"Pagan emperor Maximilian!

See, we have grass in the cauldron,

And azure flowers have bloomed.

Great is our Christian faith,//

Great is our Christian God!"

God has become even more glorious,

The holy child Kirik gave glory

Three years old less three months

With his dear mother,

With the honorable wife, with Ulita,

That glory went around the whole world,

Around the whole world, around holy Rus'.

From nowadays and for all time. Amen.

It is entirely possible that the occurrence of this version of the life of these holy martyrs in the folk tradition served as the basis for the convergence of the motif about the rescue of the Christ child by a woman 
who throws her own child into a stove with the name of the Christian martyrs Ulita and her child Kirik.

Several facts about the folk calendar support the claim that these saints were associated with fire in the folk imagination. The day of Kirik and Ulita -July 28 (July 15 old style) - is a holiday related to thunderstorms. It is possible that this conception about the day of Kirik and Ulita as a thunder holiday in the folk calendar is supported by its proximity in time to the other traditional holiday associated with thunder and storms, namely St. Elijah, August 2 (July 20 old style).

Even though classical collections of information on the folk calendar by V. I. Dal', I. P. Kalinsky, A. A. Makarenko do not contain similar data, we can support the belief that Kirik and Ulita's day was a holiday associated with thunderstorms. Take, for example, the following narratives: [Shidlovskii 1890: No. 3, p. 235]

У крестьян Курской губ. Тимского уез. за все лето чуть ли не самый страшный и самый чтимый день - это 15 июля, память мчч. Кирика, Иулиты и Авудита и св. равноапостольного князя Владимира. Муч. Авудита и св. Владимира крестьяне не знают, - знают и боятся только «Кирикия и Уликия»; это, по их словам, «вздорные святые», которые строго следят, чтобы в их праздники не работали. Вот недавно не послушались стариков - пошли на работу, - и что ж? У одного двух сыновей громом хватило, насилу отошли, у другого корова пала, третий вилами пропоролся. Нет, это вздорные святые, строго следят и долго не терпят. Хоть на Пасху готовы работать, а на Кирикия и Уликия нет. Такой ответ дали крестьяне на предложение заняться в этот день работой хоть после обеда.

Among peasants of the Kursk guberniia, Timsk uezd almost the most frightening and most commemorated day is the 15 of June, which commemorates the martyrs Kirik, Iulita and Avudit and Holy Prince Vladimir, who is ranked with the apostles. The peasants do not know the Martyr Avudit and Saint Vladimir and fear only "Kirik and Ulikia." In their words, these are "quarrelsome saints", who assiduously watch people to make sure that they do not work on their holiday. Recently, an old couple did not obey; they went to work, and then what? One of their two sons was taken by thunder, he lost his strength, a cow gored the other, the third was stabbed by a pitchfork. No, they are quarrelsome saints, they watch closely and are not very patient. Even though they (the peasants) may be willing to work on Easter, they won't on Kirik and Ulikia. The peasants reacted this way to a suggestion to work on that day even if only after dinner.

We find similar evidence in Siberian Russian materials:

Июль, 15. Кирика и Иулитты. В этот день крестьяне не убирают сена, так как день этот называют грозным; если в этот день убирают сено, то 
оно непременно сгорит огнем, потому что Кирика самого на огне мучили. (19)

July 15 . Kirik and Iulita. On this day peasants do not gather hay, because the day is called a thunderstorm day; if they gather hay on this day, then it is will soon be burned by fire, because Kirik himself was tormented by fire. [Skalozubov 1901: No, 19, p. 117] (10)

28 июля - праздник Кирики-Улиты. Это страшный праздник. Делать ничего нельзя, а то все загорится. Вот я помню, работала на тракторе, как раз в ентот день. Поехали мы на закрут. А тут вдруг пошла тучка черная, и только мы уехали с этого места, гроза как даст! И заполыхало все пламенем

The 28th of July is the holiday of Kirik and Ulita. This is a terrifying holiday. You can do nothing or everything will burn up. I remember, I was working on a tractor, on that very day. We had gone to the lumber camp. And suddenly a black cloud came along and as soon as we had driven away from there, there was a terrible thunderstorm! And everything was burned up in a fire. [GANO 173] (11)

Кирики-Улиты - праздники сердиты, ой, сердиты. Тут вот мужчина был когда-то. Тучи собираются, а него не домётаны копны. Он и говорит жене: "Пойдём, домечем". Вот они, да ещё один сосед их, поехали, сметали (тогда единолично ещё жили). Едут домой, а тучи... черно черно, прямо гроза. Легли отдохнуть. А тут ударила гроза. Загорелось что-то в полях. Поехали туда, а там копна этого мужчины горит. Тут ветром сноп вырвало из этой копны и через другие копна бросило в копну соседа. Людское сено стоит, а рядом горит. Ладно, приехали домой. Тут гроза хоп - и на крышу, а крыша соломенная. Пук соломы оторвало да хлоп - к другому на тесовую крышу. Теперь, конечно, колхоз, не скажешь же там, что в праздник работать нельзя, но дома ничего не делаю.

Kirik-Ulita are angry holidays, oh angry. There was this man once. The clouds are gathering together, but he had not yet stacked his hay. And he says to his wife: "Let's go and stack the hay." And they and one of their neighbors went and stacked hay (then they still lived as single families). They are going home and clouds, black, black, there is a thunderstorm ahead. They laid down to rest. And then the thunderstorm hit. Something in the fields caught on fire. They went over there and this man's haystacks are burning. Just then the wind tore a sheaf out of the haystack and threw it through the other haystacks into the neighbor's haystack. Other people's hay is not burning, but those nearby are burning. Okay, so they came home. Then pow, there is a thunderstorm and on the roof, the roof is straw. A piece of straw was torn off and zap, was over onto the plank roof. Now of course there is a collective farm and you don't say that you can't work on a holiday, but I don't do anything at home.

[FA OmGPU EK-3/1975, No. 12 (v)] (12) 
И Кирики-улиты, праздники сердиты. Да, девки, был такой праздник. Это летом бывает. И вот рассказывают, что если поробить на этот день, так Бог-то обязательно накажет. Вот было как-то: поработали мужики, сено метали, покос ведь как раз, вот только кончили, а сено-то и загорелось. Да и зачем в праздники-то работать, когда буден хватает

And Kirik and Ulita are angry holidays. Yes, girls, there was such a holiday. It happens in the summer. And they say that if you work on that day, then God will surely punish you. And it has happened: some men were out working, they were stacking hay, the haycutting had just ended, and the hay burned up. And why should you work on holidays anyway, when there are enough work days anyway." [FA OMGPU EK-5/1975, No. 13(b)] (13)

Кирик - мальчик, Улита - мать его, они страдали. Отец с сыном (просто легенда шла, это не у нас было) Сыну надо было метать сено. Отец говорит: «Да сегодня Кирики». Сын: “А, Кирики,- пропорет дырики!” Отец наверху стоял, сено принимал. Вот сын как-то неопытно пропорол ему вилами, ткнул его. Вот отец и говорит: «Ты же так сказал: “Кирики - пропорет дырики!”». Так и боялись Кирики: если в дуброве [лесостепь, где косили сено]: “О, завтра Кирики, давайте хоть до обеда не работать, пока идет служба.”

Kirik is a boy, Ulita is his mother, they suffered. A father and son (a legend was going around, it wasn't here), the son had to stack hay. The father says: "But today is Kirik's Day." The son: "Oh, Kirik-Schmirik (lit. is nothing but ripping holes-trans.note)!" The father was standing up above, taking the hay. Then the son somehow carelessly stabbed him with the pitchfork, poked him. And the father says: "Just as you said: "Kirik is nothing but (a joke)!" " So they were scared of Kirik's Day; if they were in the dubrova [the forest steppe, where they cut hay]: "O, tomorrow is Kirik's Day, at least let's not work before dinner, while mass is going on." [FA OmGPU EK-15/1975, No. 51] (14)

It is important that one of the legend variants we presented was recorded by the collector G. N. Potanin specifically as an example clarifiying and illustrating beliefs about the folk calendar. (15)

It appears then that the folk 'biblical' legends about the miraculous rescue of Christ and the child in the stove resulted from shared components in their history. Both are prose parallels to the religious song about the Almswife, Miloserdnaia. In two of its attestations the folk version of the life of Kirik and Ulita mixed with folk conceptions about the holiday of Saints Kirik and Ulita as a 'thunderstorm day' and served as the stimulus for associating this plot with the names of the martyred Saints Kirik and Ulita also. 


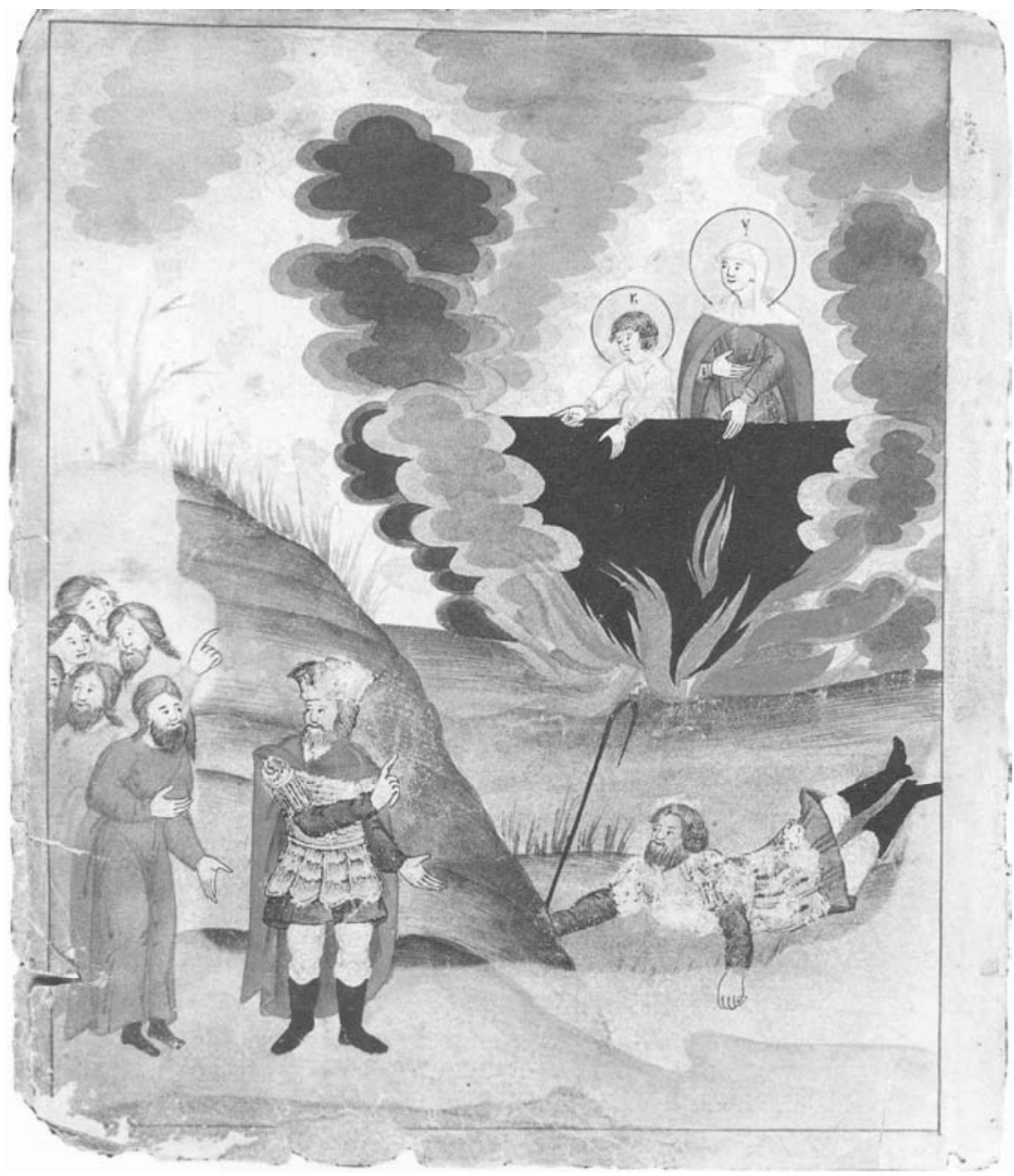

Drawing from a Siberian illuminated manuscript. The Burning of Kyrik and Ulita. Second half of the 19th century. 


\section{NOTES}

1 Recorded by E.V Trosnikov from E.F Belaia, d.o.b. 1908, Zolotukha Kalinkovichskii region, Gomel' oblast', 1983.

2 The story occurs in the section on the folk calendar "15 June. Kirik and Ulita. It is a sin to work," the text given here follows.

3 Recorded by Ovsiannikova, Nazarova in the village Pospelovo of the Bol'shekovskii region of the Omsk oblast' from A. S. Karshina.

4 Recorded by T. G. Leonova, V. Evsiukova, N. Matveeva in the village Taiga of the Znamenskii region of the Omsk oblast' from E. K. Shalunina.

5 This text has the note "Orlov guberniia, Volhovskii uezd, village Rudnevo...from the blindman Aleksei Platonovich Telenko

6 Fedotov notes that in one variant, where the Mother of God is absent, she herself is called Maria [Bezsonov 4, 137], and in another Iona [139]. See G. Fedotov, Religious Songs, p. 40.

7 For similar folk texts see: Belova 2003: 172-186; Belova 2004: numbers 130-132; Kuznetsova 2006.

8 See The Lives of the Saints for Saint Dimitrii of Rostov. Fifteenth Day (28 July).

$9 \quad$ See Varentsov 1860: 77-86: "On the holy child Kirik, about his torment, how the tsar tortures him, his former father, on the basis of their Mohammedan law," with the note: "Recorded in Nolinsk, Viatsk guberniia." The text given here is that version.

10 Told by M.M. Sadovnikov, Bol'shaia Tava, Slovodchikovsk oblast', Tarsk uezd.

11 Recorded by N. Iu. Golubkova in 1984 in the village Kadnikovo of the Mamontov region of the Altai Region from R. M. Potapova, d.o.b. 1937 (parents from the Voronezh guberniia).

12 Recorded by N. Brazhenko, N. Tkachenko in the village Chernozer'e of the Sargat region of the Omsk oblast' from O. I. Fediaeva. 13 Recorded by G. Izvekova, L Shevchenko in the village Ivanovka of the Sargat region of the Omsk oblast' from D. M. Kabakov and M.G. Kabakova.

14 Recorded by L. V. Novoselova in the village Kachesovo of the Muromtsev region of the Omsk oblast' from A. S. Kutuzova.

15 See note 2. 


\section{BIBLIOGRAPHY}

Астырев Н. На таежных прогалинах. Очерки жизни населения Восточной Сибири. Москва, 1891.

Белова О. Кто есть кто? Происхождение и судьба народов в свете “фольклорной этнологии” // Россия - XXI век. 2003. № 4. С. 172-186;

Белова, О. В.“Народная Библия”: Восточнославянские этиологическое легенды /Сост. и коммент. О.В. Беловой. М., 2004.

Безсонов П. Калеки перехожие. Собрание стихов и исследование. Москва., 1863. Вып. 4.

Варенцов, В. Сборник русских духовных стихов, составленный В. Варенцовым. СПб., 1860.

Добровольский В.Н. Смоленский этнографический сборник. Ч. 1. СПб., 1891.

Кузнецова В.С. Пчела и муха в легендах и поверьях фольклорной Библии (русские сибирские записи). Кирпичник. Зборник статей в честь 65 летия С. Ю. Неклюдова. (в печати).

Потанин Г.Н. Юго-западная часть Томской губернии в этнографическом отношении Этнографический сборник, издаваемый имп. Русским географическим обществом. Вып. 6 . СПб., 1864.

Скалозубов Н. Народный календарь// Ежегодник Тобольского губернского музея Тобольск, 1901. Вып. 12.

Федотов Г. Стихи духовные (Русская народная вера по духовным стихам) М., 1991.

Шидловский, Г.Р. Кирик и Улита. Сообщение//

Этнографическое обозрение. 1890, № 3 (кн. 6).

\section{ARCHIVAL SOURCES}

FA OmGPU (ФА ОмГПУ) - Фольклорный архив Омского государстенного педагогического университета

GANO (ГАНО) - Государственный архив Новосибирской обл. ф. М.Н. Мельникова

RGALI (РГАЛИ) - Российский государственный архив литературы и искусства 